\title{
COMPARATIVE ANALYSIS OF IATROGENIC INJURY OF BILIARY TRACT IN LAPAROTOMIC AND LAPAROSCOPIC CHOLECYSTECTOMY
}

\author{
Análise comparativa de lesão iatrogênica de vias biliares em colecistectomias laparotômicas e videolaparoscópicas
}

André Augusto FORTUNATO, João Kleber de Almeida GENTILE, Diogo Peral CAETANO,

Marcus Aurélio Zaia GOMES, Marco Antônio BASSI

From the Departament of Surgery of Hospital Ipiranga UGA-II (Serviço de Cirurgia Geral e Gastrocirurgia do Hospital Ipiranga UGA-II), São Paulo, SP, Brazil
ABSTRACT - Background: Iatrogenic injury to the bile ducts is the most feared complication of cholecystectomy and several are the possibilities to occur. Aim: To compare the cases of iatrogenic lesions of the biliary tract occurring in conventional and laparoscopic cholecystectomy, assessing the likely causal factors, complications and postoperative followup. Methods: Retrospective cohort study with analysis of records of patients undergoing conventional and laparoscopic cholecystectomy. All the patients were analyzed in two years. The only criterion for inclusion was to be operative bile duct injury, regardless of location or time of diagnosis. There were no exclusion criteria. Epidemiological data of patients, time of diagnosis of the lesion and its location were analyzed. Results: Total of 515 patients with gallstones was operated, 320 (62.1\%) by laparotomy cholecystectomy and 195 by laparoscopic approach. The age of patients with bile duct injury ranged from 29-70 years. Among those who underwent laparotomy cholecystectomy, four cases were diagnosed $(1.25 \%)$ with lesions, corresponding to $0.77 \%$ of the total patients. No patient had iatrogenic interventions with laparoscopic surgery. Conclusion: Laparoscopic cholecystectomy compared to laparotomy, had a lower rate of bile duct injury.
HEADINGS - Cholecystectomy.

Cholecystectomy, laparoscopic. Bile duct.
RESUMO - Racional: A lesão iatrogênica das vias biliares representa a complicação mais temida na colecistectomia e vários são seus fatores desencadeantes. Objetivos: Estudar comparativamente os casos de lesões iatrogênicas de vias biliares ocorridas em colecistectomias convencionais e videolaparoscópicas, avaliando os prováveis fatores causais, complicações e o seguimento pósoperatório. Método: Estudo de coorte retrospectiva, com análise de prontuários dos pacientes submetidos à colecistectomias convencionais e videolaparoscópicas. Foram analisados todos os pacientes operados no período de dois anos. O critério de inclusão único foi o de existir lesão operatória da via biliar, independentemente de sua localização ou tempo de diagnóstico. Não houve critérios de exclusão. Foram analisados dados epidemiológicos dos pacientes, tempo de diagnóstico da lesão e sua localização. Resultados: Total de 515 pacientes portadores de litíase biliar foi operado, senod $320(62,1 \%)$ por colecistectomia laparotômica e 195 por videolaparoscópica. A idade dos pacientes com lesão de via biliar variou de 29-70 anos. Entre os submetidos à colecistectomia laparotômica, foram diagnosticados quatro casos $(1,25 \%)$ com lesão de via biliar, correspondendo à $0,77 \%$ do total de pacientes. Nenhum paciente teve iatrogênese com a videocirurgia. Conclusão: A colecistectomia videolaparoscópica, comparativamente à colecistectomia laparotômica, apresentou menor taxa de lesão de via biliar.

\section{DESCRTORES}

Colecistectomia biliares.
Colecistectomia. laparoscópica. Ductos
C holecystectomy began to be held in the late $19^{\text {th }}$ century and was first described in 1882 by Carl Langenbuch. In the $20^{\text {th }}$ century its technical principles were created; major innovations have occurred in the last 25 years with the emergence of videolaparoscopic surgery $1,2$.

Surgical removal of the gallbladder is indicated in the treatment of biliary lithiasis and its complications, as well as neoplasms of the gallbladder. Iatrogenic injury to the bile ducts is the most feared complication, with an incidence of around 0.2 to $2.9 \%{ }^{3}$. Factors such as laparoscopy, acute cholecystitis, scleroatrophic gallbladder, anatomic variations of the biliary tract, the curve for new surgeons and residents, are seen as the main causes of the higher incidence of iatrogenic injuries. ${ }^{10}$

The management of patients with these lesions is very complex, requiring experienced surgeons and mostly specialized services for the treatment of this complication. The prognosis is closely related to clinical conditions and the time between the identification of the lesion and surgical treatment ${ }^{5,6,12}$.

Given the learning curve for new surgeons and the presence of a higher incidence of iatrogenic lesions of the bile ducts, the aim of this study was to analyze comparatively the two standard procedures for cholecystectomy - laparotomy and laparoscopy - in order to verify the iatrogenic injuries they may cause. 
METHODS

A retrospective cohort study was performed with analysis of charts of the Department of General Surgery, Hospital Ipiranga UGA - II, São Paulo, SP, Brazil. All patients that underwent laparotomic and laparoscopic cholecystectomies from $01 / 01 / 2010$ to $31 / 12 / 2011$ were analyzed. The only criterion for inclusion was to be operative bile duct injury, regardless of location or time of diagnosis. There were no exclusion criteria. Information on gender, age, acute or chronic symptoms, type of operation, time of diagnosis of the lesion and its location were evaluated. All patients underwent general anesthesia and operated by residents of the second year of general surgery, guided by assistant surgeons or preceptors.

\section{RESULTS}

A total of 515 patients with cholelithiasis, diagnosed by clinical and imaging examination, were operated being 320 (62.1\%) by laparotomy and 195 (37,9\%) by laparoscopy. The age of patients with bile duct injury ranged from 29 to 70 years (mean 49.2). Among those who underwent laparotomy cholecystectomy, four cases were diagnosed (1.25\%) with lesions of the biliary tract, corresponding to $0.77 \%$ of the total patients. No patient had iatrogenic interventions with laparoscopic surgery (Table 1).

TABLE 1 - Comparative analysis of lesion of bile duct between the laparotomic and laparoscopic cholecystectomy approach

\begin{tabular}{|l|c|c|}
\hline & N & Lesions \\
\hline Laparatomy cholecystectomy & $320(62,1 \%)$ & $4(1,25 \%)$ \\
\hline Laparoscopic cholecystectomy & $195(37,9 \%)$ & 0 \\
\hline Total & 515 & 4 \\
\hline
\end{tabular}

The lesions were diagnosed intra- and postoperatively. The ones recognized intraoperatively had: one injury to the right hepatic duct and one cystic duct avulsion; later, two cases with stenosis of the common bile duct in 17 and 41 days postoperatively diagnosis done by endoscopic retrograde cholangiopancreatography. In one of these cases there was reference to accessory bile duct ligation, while in the other no mention of complication during surgery was written.

Three cases ( $75 \%$ ) of bile duct injury were symptomatic at the time of re - admission and were operated by emergency general surgery service and a case was electively treated at the same service, who died from complications of the biliary injury. No biliary lesions were diagnosed in 195 patients (37.9 \%) undergoing laparoscopic cholecystectomy.

\section{DISCUSSION}

Cholecystectomy is the most common elective abdominal operation in the world and its iatrogenic injury is the most feared complication. The incidence of this lesion is about one for every 800 procedures $^{6,14}$. After the introduction of laparoscopic surgery, indicated as the gold standard in the treatment of cholecystitis, the incidence increased to one in 120 procedures, significant increase, due to the technical difficulty and learning curve of the procedure, according to most authors ${ }^{7,9,14}$.

The present study demonstrated rate of bile duct injury in $0.77 \%$ of cases, all underwent laparotomy cholecystectomy (1.25\%). The incidence reported in the literature varies between $0.1-0.5 \%$ for this access, and 0.07 to $0.95 \%$ for laparoscopic cholecystectomy. In this study there was no bile duct injury with laparoscopic surgery.

Several factors are implicated in the pathogenesis of bile duct injury as male gender, acute cholecystitis, surgical approach and anatomical variation; the latter, is the responsible for the majority of technical difficulty of cholecystectomy. The anatomical variation is reported present between $6-25 \%$ of patients with bile duct injury. The most common anomaly is an aberrant right hepatic duct in hepatobiliary triangle (Calot) 6,10,16.

Early identification of biliary injury is of fundamental importance for the treatment; however, it is only diagnosed in less than half of the cases. This fact results in severe late complications such as biliary cirrhosis, liver failure and death. One case in this series died from complications of bile duct injury.

Among various existing classifications for injury to the bile duct stands out Bismuth's one $(1982)^{7,12}$, more used in late stenosis mainly as consequence to thermal injury or bile duct ligature commonly associated with local/regional inflammatory reaction. The bad medical records and late re-intervention difficult classification in this case series ${ }^{5,18}$.

The first goal in treatment is sepsis and bile leak control. Surgical reconstruction after resolution of the initial sepsis is not urgent and can be done a few weeks posteriorly.

Roux-en-Y hepaticojejunostomy is the best treatment option and more often employed. Another form of treatment is the use interventional radiology placing $\mathrm{T}$ (Kehr) device in minor injuries, followed by dilation or placement of endo- prosthesis ${ }^{4,9,20}$.

Clearly the experience of the surgeon reduces the incidence of early and late complications of biliary tract injuries, both in open or in laparoscopic approaches.

\section{CONCLUSION}

Laparoscopic cholecystectomy compared to laparotomy cholecystectomy had a lower rate of bile duct injury.

\section{REFERENCES}

1. Aguiar GB, Oliveira GIB, Silva JBS, Santos LS e Vieira SC. Lesão iatrogênica de vias biliares. Rev Col Bras Cir 2005; 32(2):69-73. Lau KN, Sindram D, Agee D. Bile duct injury after single incision laparoscopic cholecystectomy. JSLS 2010;14:587-591.

2. Buddingh KT, Nieuwenhuijs VB, van Buuren $L$ and Hulscher JBF. Intraoperative assessment of biliary anatomy for prevention of bile duct injury: a review of current and future patient safety interventions. Surg Endosc 2011;25:2449-2461.

3. Chiruvella A, Sarmiento JM, Sweeney JF, Lin E and Davis SS. Iatrogenic combined bile duct and right hepatic artery injury during single incision laparoscopic cholecystectomy. JSLS 2010; 14:268-271.

4. Connor S and Garden J. Bile duct injury in the era of laparoscopic cholecystectomy. British J Surg 2006;93:158-168.

5. Crema E. Lesões iatrogênicas da vias biliares: como prevenir. Arq Bras Cir Dig 2010; 23(4):215-216.

6. Fathy $\mathrm{O}$ et al. Post-cholecystectomy biliary injuries: one Center experience. Hepatol Gastroenterol 2011;58:719-724.

7. Garden CS. Lesão iatrogênica da via biliar e videocirurgia. British J Surg 2006; 93:158-168.

8. Girometti R, Brondani G, Cereser L, Como G, Del Pin M and BazzocchiM.Post-cholecystectomysyndrome:spectrum ofbiliary findings at magnetic resonance cholangiopancreatography. British Jour of Radiol 2010; 83:351-361.

9. Jablonska B and Lampe P. Iatrogenic bile duct injuries: etiology, diagnosis and management. World J Gastroenterol 2009;15(33):4097-4104.

10. Lau WY and Lai ECH. Classification of iatrogenic bile duct injury. Hepatobiliary Pancreat Dis Int 2007;6:459-463. 
11. Lillemoe KD. Melton GB, Cameron JL, Pitt HA and Campbell KA Postoperative bile duct strictures: management and outcome in the 1990s. Annals of Surgery 2000;232(2):430-441.

12. Linhares BL, Magalhães AG e Soares PM. Lesão iatrogênica de via biliar pós-colecistectomia. Rev Col Bras Cir 2011;38(2):95-99.

13. Manouras A, Pararas N, Antonakis $P$ and Lagoudiannakis EE. Management of major bile duct injury after laparoscopic cholecystectomy: a case report. J Med Case Reports 2009;44(3):16.

14. Milcent M, Santos EG e Bravo GP. Lesão iatrogênica da via biliar principal em colecistectomia videolaparoscópica. Rer Col Bras Cir 2005;(6):332-336.

15. Nordin A, Grönroos JM and Mäkisalo H. Treatment of biliary complications after laparoscopic cholecystectomy. Scandinavian J Surg 2011;100:42-48.
16. Santibánes E, Ardiles $V$ and Pekolj J. Complex bile duct injuries: management. HPB 2008;10:4-12.

17.Shamin M, Urooj R and Dawani A. Post-cholecystectomy biliary injuries: diagnosis and management. Pakistan J Surg 2007;23(3):166-168

18. Wu JS, Peng C, Mao XH and Lv P. Bile duct injuries associated with laparoscopic and open cholecystectomy: sixteen-year experience. World J Gastroenterol 2007;13(16):2374-2378.

19. Neves CC, Penteado S, Zilberstein B, Neves G, Gabriel Neto S Oliveira EC. Incidência e resultado do tratamento das lesões da via biliar em colecistectomia por laparotomia. ABCD Arq Bras Cir Dig. 2004;17:38-41.

20. De Wit LT, Raws AJ, Gouma DJ. Surgical management of bile duct injury. Scand J Gastroenterol. 1999;34(Suppl 230):89-94. 